\title{
Effect of Chitosan Coating Incorporated with Artemisia fragrans Essential Oil on Fresh Chicken Meat during Refrigerated Storage
}

\author{
Milad Yaghoubi ${ }^{1}$, Ali Ayaseh ${ }^{1}$, Kazem Alirezalu ${ }^{2, * \mathbb{D}}$, Zabihollah Nemati ${ }^{3}$ (D) , Mirian Pateiro ${ }^{4}$ (D) \\ and José M. Lorenzo $4,5, *$ (D)
}

1 Department of Food Science and Technology, Faculty of Agriculture, University of Tabriz, Tabriz 51666, Iran; m.yaghoubi97@ms.tabrizu.ac.ir (M.Y.); ayaseh@tabrizu.ac.ir (A.A.)

2 Department of Food Science and Technology, Ahar Faculty of Agriculture and Natural Resources, University of Tabriz, Tabriz 51666, Iran

3 Department of Animal Science, Ahar Faculty of Agriculture and Natural Resources, University of Tabriz, Tabriz 51666, Iran; znemati@tabrizu.ac.ir

4 Centro Tecnológico de la Carne de Galicia, Parque Tecnológico de Galicia, rúa Galicia n ${ }^{\circ} 4$, San Cibrao das Viñas, 32900 Ourense, Spain; mirianpateiro@ceteca.net

5 Área de Tecnología de los Alimentos, Facultad de Ciencias de Ourense, Universidad de Vigo, 32004 Ourense, Spain

* Correspondence: kazem.alirezalu@tabrizu.ac.ir (K.A.); jmlorenzo@ceteca.net (J.M.L.)

check for updates

Citation: Yaghoubi, M.; Ayaseh, A.; Alirezalu, K.; Nemati, Z.; Pateiro, M.; Lorenzo, J.M. Effect of Chitosan Coating Incorporated with Artemisia fragrans Essential Oil on Fresh Chicken Meat during Refrigerated Storage. Polymers 2021, 13, 716 https://doi.org/10.3390/ polym 13050716

Academic Editor: Hélène de Baynast

Received: 26 January 2021

Accepted: 22 February 2021

Published: 26 February 2021

Publisher's Note: MDPI stays neutral with regard to jurisdictional claims in published maps and institutional affiliations.

Copyright: (c) 2021 by the authors. Licensee MDPI, Basel, Switzerland. This article is an open access article distributed under the terms and conditions of the Creative Commons Attribution (CC BY) license (https:/ / creativecommons.org/licenses/by/ $4.0 /)$.
Abstract: The present study was conducted to assess the impact of chitosan coating (1\%) containing Artemisia fragrans essential oil (500, 1000, and 1500 ppm) as antioxidant and antimicrobial agent on the quality properties and shelf life of chicken fillets during refrigerated storage. After packaging meat samples, physicochemical, microbiological, and organoleptic attributes were evaluated at 0,3 , 6,9 , and 12 days at $4{ }^{\circ} \mathrm{C}$. The results revealed that applied chitosan $(\mathrm{CH})$ coating in combination with Artemisia fragrans essential oils (AFEOs) had no significant $(p<0.05)$ effects on proximate composition among treatments. The results showed that the incorporation of AFEOs into $\mathrm{CH}$ coating significantly reduced $(p<0.05) \mathrm{pH}$, thiobarbituric acid reactive substances (TBARS), and total volatile base nitrogen (TVB-N), especially for $1 \% \mathrm{CH}$ coating +1500 ppm AFEOs, with values at the end of storage of 5.58, 1.61 , and 2.53, respectively. The coated samples also displayed higher phenolic compounds than those obtained by uncoated samples. Coated chicken meat had, significantly $(p<0.05)$, the highest inhibitory effects against microbial growth. The counts of TVC (total viable counts), coliforms, molds, and yeasts were significantly lower $(p<0.05)$ in $1 \% \mathrm{CH}$ coating +1500 ppm AFEOs fillets $(5.32$, 3.87, and 4.27 Log CFU/g, respectively) at day 12. Organoleptic attributes of coated samples also showed the highest overall acceptability scores than uncoated ones. Therefore, the incorporation of AFEOs into $\mathrm{CH}$ coating could be effectively used for improving stability and shelf life of chicken fillets during refrigerated storage.

Keywords: chitosan; Artemisia fragrance; shelf life; chicken fillets; coating

\section{Introduction}

Chicken meat with low amount of lipids and low cost of production not only is a rich source of essential amino acids with high biological value but also is an excellent origin of unsaturated fatty acids and minerals for human body [1]. Its high $\mathrm{pH}$ and moisture content make it so that, at aerobic conditions, chicken meat is susceptible to lipid and protein oxidations and microbial growth, leading to a decrease in shelf life [2,3]. Moreover, chicken meat is highly perishable by pathogenic bacteria, such as Listeria monocytogenes, Escherichia coli, Campylobacter jejuni, and Salmonella spp. [4]. Today, the major challenge of meat industry is to increase the stability, shelf life, and overall acceptability of the chicken meat by delaying lipid oxidation and preventing microbial growth.

The negative health effects associated with the use of sodium nitrate, benzoic acid, and potassium sorbate as chemical preservatives have recently led researchers and meat 
industries to focus on applying natural preservatives, such as bacteriocins [5], organic acids [6], essential oils (EOs) [7], or chitosan [2], to delay the lipid and protein oxidations. Plant extracts and EOs from natural origins, generally recognized as safe (GRAS) by the Food and Drug Administration (FDA), have been widely studied [7-10]. These compounds have been widely used as antimicrobial and antioxidant compounds in food industry due to the presence of terpenoids and phenolic components in their composition [11,12].

Edible coating is a promising technology of active packaging that includes food, packaging, and preservation in a single concept, allowing through the use of biopolymers generated from food industry co-products or underutilized sources of lipids, polysaccharides, or proteins develop an effective system that preserves the quality of food during the shelf life of the product [13]. There is a wide spectrum of natural antioxidants and antimicrobials derived from plants, which have been included as extracts or EOs in films and coatings [14,15]. In this regard, EOs of clove [16], ginger [1], and oregano [17] have been used as antimicrobials in chicken fillets. Chitosan, characterized by high film forming ability, good barrier properties, non-polluting material, biodegradability, non-toxicity, and biocompatibility properties $[18,19]$, and with high antioxidant activity and high antimicrobial effects against wide spectrum of bacteria, yeast, and molds [20,21], has been widely used as antimicrobial coatings and films in meat products. Furthermore, many researchers have been indicated the efficacy of chitosan edible coatings or films to delay quality deterioration and putrefaction in foods [22]. In this regard, high antimicrobial and antioxidant properties of chitosan coatings combined with natural antioxidants have been demonstrated in beef [23], chicken breast meat [24], pork slices [25], and refrigerated pork [26].

The genus Artemisia with more than 500 species belongs to Asteraceae family [27]. Artemisia fragrans EO (AFEOs) is not only a rich source of $\beta$-thujone, $\alpha$-thujone, camphor, and 1,8-cineole but also has high antioxidant and antibacterial properties [28,29]. In this regard, techno-functional properties of Artemisia have been indicated in meat and meat products, such as breast and thigh muscles in broilers [30] and Hy-line Brown male chickens [31]. However, there was no reports on chitosan coatings incorporated with AFEOs in chicken meat during storage. Therefore, the aim of this study was to evaluate the preservative effects of this coating on chicken meat during refrigerated storage.

\section{Materials and Methods}

\subsection{Preparation of Artemisia Fragans Essential Oil (AFEOs)}

Clevenger-type apparatus was utilized to production of AFEOs. Dry material of $A$. fragrans $(400 \mathrm{~g})$ was immersed in water $(1000 \mathrm{~mL})$ and subjected to hydro-distillation. The obtained EO was kept in black glass bottle and stored at $4{ }^{\circ} \mathrm{C}$ for further use.

\subsection{AFEOs Isolation}

The gas chromatographic-mass spectrometric (GC-MS) apparatus was used for AFEOs composition (Varian, mod. Saturn 2100T, San Fernando, CA, USA). A fused-silica capillary column ( $50 \mathrm{~m} \times 0.22 \mathrm{~mm}, 0.25 \mu \mathrm{m}$ film thickness) and helium was used as the carrier gas $\left(1 \mathrm{~cm}^{3} / \mathrm{min}\right)$ were used for compounds separation. Injector and detector temperatures were $280^{\circ} \mathrm{C}$ (splitless $20 \mathrm{~cm}^{3} / \mathrm{min}$ ) and $260^{\circ} \mathrm{C}$, respectively. Oven condition was $50{ }^{\circ} \mathrm{C}$ increased to $250^{\circ} \mathrm{C}$ at a rate of $2{ }^{\circ} \mathrm{C} / \mathrm{min}$ and held for $60 \mathrm{~min}$. The fatty acid methyl ester (FAMEs) were identified by comparison of peaks retention time with standard FAMEs (SigmaAldrich, Steinheim, Germany), and the peaks area reported as component percentage [29].

\subsection{Preparation of Meat Samples}

The whole experiment was repeated with a separate source of skinless and boneless chicken breast in five batches during three successive days ( 5 treatments $\times 5$ time periods $\times 3$ repetitions $\times 3$ runs). The raw material (chicken meats) was bought (weighted between $2.5-5 \mathrm{~kg}$ ) from a local slaughterhouse and transported directly to laboratory in ice boxes. Ten g chitosan (95\% deacetylation degree) was dissolved in $1 \%$ acetic acid, reached to 
$1000 \mathrm{~mL}$. Then, AFEOs was mixed at different concentrations (500, 1000, and $1500 \mathrm{ppm}$ ). After that, Tween 80 as a surfactant agent was added to treatment solutions and mixed for $1 \mathrm{~min}$. Based on the previous data on 1\% chitosan concentration [32], the chicken breast meats were randomly divided into five groups as follows: T1: Negative control; T2: Treated with distilled water; T3: $1 \%$ chitosan $(\mathrm{CH})$ coating + 500 ppm AFEOs; T4: $1 \% \mathrm{CH}$ coating +1000 ppm AFEOs; T5: $1 \% \mathrm{CH}$ coating +1500 ppm AFEOs. All meat samples, cut with a sterile knife $(1 \times 3 \times 6 \mathrm{~cm})$, were immersed in prepared solutions for $1 \mathrm{~h}$ at $4{ }^{\circ} \mathrm{C}$, and, finally, the samples were drained for $2 \mathrm{~min}$ and packaged in low density polyethylene bags for evaluation of chemical composition, $\mathrm{pH}$, phenolic compounds, total volatile base nitrogen (TVB-N), thiobarbituric acid reactive substances (TBARS) values, color parameters, organoleptic attributes, and microbial counts at $0,3,6,9$, and 12 days of refrigerated storage.

\subsection{Proximate Composition and $\mathrm{pH}$}

Proximate composition of chicken fillet samples, including lipid, ash, protein, and moisture, were determined in triplicate according to Karsli et al. [32]. For evaluation of $\mathrm{pH}$, chicken fillets were homogenized in proportion of 1:10 $(w / v)$ with distilled water and analyzed with a pH meter (Hanna, Methrom, Switzerland).

\subsection{Measurement of Thiobarbituric Acid Reactive Substances (TBARS)}

The TBARS values of chicken fillets were analyzed according to methodology of Liu et al. [33]. The reactions of thiobarbituric acid with the oxidation products lead to the production of compounds which was measured in a spectrophotometer (Hitachi, Ltd., Tokyo, Japan) at $532 \mathrm{~nm}$. 1,1,3,3-tetraethoxypropane (TEP) was used to prepare the standard curve at concentrations between of 0 to $10 \mathrm{ppm}$, and the data were expressed as $\mathrm{mg}$ malondialdehyde $/ \mathrm{kg}(\mathrm{mg} \mathrm{MDA} / \mathrm{kg}$ ) of chicken meat samples.

\subsection{Determination of Total Volatile Nitrogen (TVB-N)}

Total volatile nitrogen (TVB-N) of meat samples were evaluated by Kjeldahl method with a vapor distillation according to Goulas and Kontominas [34]. The data were reported as $\mathrm{mg} / 100 \mathrm{~g}$ of chicken meat samples.

\subsection{Total Phenolic Content (TPC)}

According to Liu et al. [33], total phenolic contents of chicken fillets were evaluated using Folin-Ciocalteu reagent. Firstly, $50 \mathrm{~g}$ of chicken meat and $100 \mathrm{~mL}$ of boiled distilled water were mixed together and left at room temperature for $20 \mathrm{~min}$. After cooling, the obtained solution was filtered and mixed with Folin-Ciocalteau reagent $(2.5 \mathrm{~mL})$ and saturated sodium carbonate solution $(5 \mathrm{~mL})$ in test tubes. Finally, the solution was vortexed and held in a dark place (1 h). UV-vis spectrophotometer Hitachi U-3210 (Hitachi, Ltd., Tokyo, Japan) was utilized for the evaluation of TPC at $700 \mathrm{~nm}$. Standard curve was prepared with Gallic acid, and the data was reported as $\mathrm{mg} / 100 \mathrm{~g}$ of Gallic acid equivalents (GAE).

\subsection{Determination of Color Parameters}

Color indices ( $\mathrm{L}^{*}$ : lightness, $\mathrm{a}^{*}$ : redness, $\mathrm{b}^{*}$ : yellowness) on the surface of the chicken samples were evaluated according to the method proposed by Leon et al. [35] using a simple digital imaging system. The chicken fillets were sized into $1 \times 3 \times 6 \mathrm{~cm}$ thickness to analyze the color. Digital camera with 16 mega-pixels under suitable light at $25^{\circ} \mathrm{C}$ and standard plates for instrument calibration were used for capturing the image. Photoshop software was used to analyze the pictures and report the data.

\subsection{Microbiological Analysis}

The microbiological evaluation was performed on days $0,3,6,9$, and 12 of the storage period. Twenty-five g of chicken samples were mixed in sterile lab-blender (Neutec, Paddle Lab Blender, Farmingdale, NY, USA) with $225 \mathrm{~mL}$ of peptone water $(0.1 \% w / v$; Difco, 
Becton Dickinson, East Rutherford, NJ, USA) for $3 \mathrm{~min}$. Serial dilutions were prepared with $0.1 \%$ peptone water. PCA (Plate Count Agar, Merck, Darmstadt, Germany), VRB (Violet Red Bile Agar, Merck, Darmstadt, Germany) and DRBC (Dichloran Rose-Bengal Chloramphenicol Agar, Merck, Darmstadt, Germany) were employed as nutrient broths for the enumeration of total viable counts (TVC), coliform, mold, and yeast counts, respectively, by pour plate technique. TVC, coliform, mold, and yeast were incubated for $48-72 \mathrm{~h}$ at 30 ${ }^{\circ} \mathrm{C}, 24 \mathrm{~h}$ at $37^{\circ} \mathrm{C}$, and 5 days at $25^{\circ} \mathrm{C}$, respectively. The results were reported as $\log 10$ colony forming unit/g (Log CFU/g) of chicken samples [36].

\subsection{Sensory Properties}

The effects of $\mathrm{CH}$ in combination AFEOs on sensory attributes of chicken fillets were evaluated at the end of refrigerated storage. Seventy-two consumers (twenty-four male and forty-eight females) were selected as panelists, all of whom had prior experience about sensory attributes of many kinds of fresh meats. The sensory evaluation consisted of six sessions with twelve panelists for each sitting. A randomized (complete) block design was conducted. The sausage samples were cut into 3-mm thick cubes at room temperature, individually labeled with aleatory numbers and randomly served. Overall acceptability, odor, color, texture, and freshness of chicken fillets were analyzed using hedonic scale (1: really dislike, 5: really like). For increasing accuracy of sensory analysis, between each testing, crackers (unsalted) and water were utilized. Overall acceptability scores were also obtained by average of odor, color, texture, and freshness scores [37].

\subsection{Statistical Analysis}

The experimental data resulted from 5 treatments $\times 5$ time periods $\times 3$ repetitions $\times 3$ runs were analyzed using the statistical software SAS (v.9, SAS Institute Inc., Cary, NC, USA). Normal distribution and variance homogeneity had been previously determined (Shapiro-Wilk). Random block design, considering a mixed linear model, including replicate as a random effect and chicken meat treatment and storage time as fixed effects, were used for the evaluation of $\mathrm{pH}$, TVB-N, and TBARS values, phenolic content, color indexes, sensory characteristics, and microbiological counts. ANOVA $(p<0.05)$, followed by Tukey's test, was used for moisture, protein, fat, and ash contents. Panelists and sessions were used as random effects for the sensory characteristics. All data were expressed as mean values \pm standard error in tables and figures, but the results of chemical properties were expressed as mean values \pm standard deviation.

\section{Results and Discussion}

\subsection{Gas Chromatography-Mass Spectrometry Analysis}

The volatile chemical components of AFEOs are shown in Table 1 . The data showed that thujone $(40.21 \%)$ had the highest content and followed by 1,8-Cineole $(21.04 \%), 1-$ camphor (11.87\%), and isobornyl alcohol (3.49\%). All of the identified volatile component indicated $99.46 \%$ of total AFEOs. The results of the present research were similar by Baldino et al. [29] findings on camphor (14.63\%) as one of the main component of AFEOs. Other studies reported that carvacrol was a volatile component of AFEOs [38]. These disagreements maybe caused by climate conditions, soil composition, genetic, stage of maturity, cultivars, plant organs, and extraction conditions, as well as the variations in cultivation [38].

\subsection{Effect of $\mathrm{CH}$-AFEOs Coating on Proximate Composition and $p H$}

The proximate composition among treatments showed similar values for ash, fat, protein and moisture contents, which indicates that chitosan and AFEOs had no significant $(p>0.05)$ effects on chicken fillets composition (Table 2). The results of present research are in agreement with those observed by Alirezalu et al. [21]. The authors showed that the inclusion of natural antioxidants in $\varepsilon$-polylysine, chitosan, and nisin had no significant effects on frankfurter-type sausage proximate composition. Agregán et al. [39] also 
reported similar results in the chemical composition of pork patties by applying natural antioxidant (macroalgae Fucus vesiculosus extract). In the same way, de Carvalho et al. [40] evaluated the impact of guarana (Paullinia cupana) seed and pitanga (Eugenia uniflora L.) leaf extracts on lamb patties and reported no significant differences in chemical compositions among treatments.

Table 1. Essential oil components of Artemisia fragrance used for chicken meat treatments.

\begin{tabular}{|c|c|}
\hline Name & Area (\%) Essential Oil \\
\hline 4-carene & 0.42 \\
\hline Methyl Cinnamat & 0.25 \\
\hline 3-carene & 0.20 \\
\hline$\beta$-Cymene & 1.37 \\
\hline p-Cymene & 0.45 \\
\hline Camphene & 0.9 \\
\hline Cis-Salvene & 0.2 \\
\hline 1-Phellandrene & 0.47 \\
\hline Sabinene & 0.46 \\
\hline$\alpha$-Terpinolene & 0.75 \\
\hline$\alpha$-Pinene & 0.2 \\
\hline$\beta$-Phellandrene & 0.51 \\
\hline$\beta$-Pinene & 0.19 \\
\hline$\gamma$-Terpinene & 0.69 \\
\hline verbenene & 0.18 \\
\hline 1,8-Cineole & 21.04 \\
\hline 4-Terpineol & 2.65 \\
\hline 1-Camphor & 11.87 \\
\hline cis-Jasmone & 0.54 \\
\hline Isobornyl alcohol & 3.49 \\
\hline 1-Carvone & 1.15 \\
\hline Myrtenal & 0.17 \\
\hline Myrtenol & 2.16 \\
\hline Pinocarvone & 0.25 \\
\hline Piperitone & 0.98 \\
\hline Sabinyl acetate & 1.63 \\
\hline Thujone & 40.21 \\
\hline Sesquiterpenes (ST) & 0.37 \\
\hline Germacrene-D & 0.38 \\
\hline Copaene & 0.36 \\
\hline Oxygentated Sesquiterpenes (OST) & 2.08 \\
\hline Carvacrol & 1.12 \\
\hline Cis-Davanone & 0.94 \\
\hline Others (OTH) & 0.40 \\
\hline 1-Octen-3-ol & 0.46 \\
\hline
\end{tabular}

On the other hand, $\mathrm{pH}$ values in meat and meat products can highly affected microbial balance and function of bacteriostatic, which can lead to a low shelf life. These values are usually under 6 in fresh meat [41]. The changes in $\mathrm{pH}$ values of chicken meat between coated treatments during refrigerated storage are showed in Figure 1. As expected, the $\mathrm{pH}$ of the chicken fillet samples increased among refrigerated storage. The production of lactic acid bacteria and the accumulation of alkaline components produced by psychrotrophic bacteria and the autolytic activity of the autochthonous enzymes may be the main reason for the change of $\mathrm{pH}$ during storage [42,43]. This aforementioned increase was significantly $(p<0.05)$ higher in uncoated samples (negative control and treated with distilled water). At day 12 , treated samples with distilled water displayed higher values than those obtained in fillets coated with $1 \% \mathrm{CH}+1500 \mathrm{ppm}$ AFEOs (7.01 vs. 5.55, respectively). The antibacterial properties of chitosan and AFEOs could be responsible for the lower $\mathrm{pH}$ values observed in coated samples. This impact of chitosan films on $\mathrm{pH}$ of meat and meat products are in agreement with the results found by other authors in chilled meat [44]. In the 
same way, Vaithiyanathan et al. [45] and Berizi et al. [46] reported similar behaviour in chicken meat and other food model systems treated with chitosan in combination with natural preservatives.

Table 2. Chemical composition (\%) of chicken meat coated with chitosan containing AFEOs during storage at $4{ }^{\circ} \mathrm{C}$.

\begin{tabular}{ccccc}
\hline Sample & Moisture & Fat & Ash & Protein \\
\hline T1 & $76.51 \pm 1.63$ & $1.37 \pm 0.14$ & $1.20 \pm 0.04$ & $20.90 \pm 0.96$ \\
T2 & $76.02 \pm 1.79$ & $1.40 \pm 0.07$ & $1.10 \pm 0.09$ & $20.92 \pm 0.99$ \\
T3 & $76.26 \pm 1.76$ & $1.41 \pm 0.14$ & $1.02 \pm 0.02$ & $21.11 \pm 0.35$ \\
T4 & $76.15 \pm 0.42$ & $1.39 \pm 0.23$ & $1.10 \pm 0.03$ & $21.34 \pm 0.83$ \\
T5 & $76.89 \pm 1.44$ & $1.41 \pm 0.09$ & $1.14 \pm 0.04$ & $20.51 \pm 0.85$ \\
\hline
\end{tabular}

The results were expressed as mean values \pm standard deviation. T1: Negative control; T2: Distilled water; T3: $1 \%$ chitosan $(\mathrm{CH})$ coating + 500 ppm AFEOs; T4: $1 \% \mathrm{CH}$ coating + 1000 ppm AFEOs; T5: $1 \%$ CH coating + 1500 ppm AFEOs. There were no significant differences among treatments.

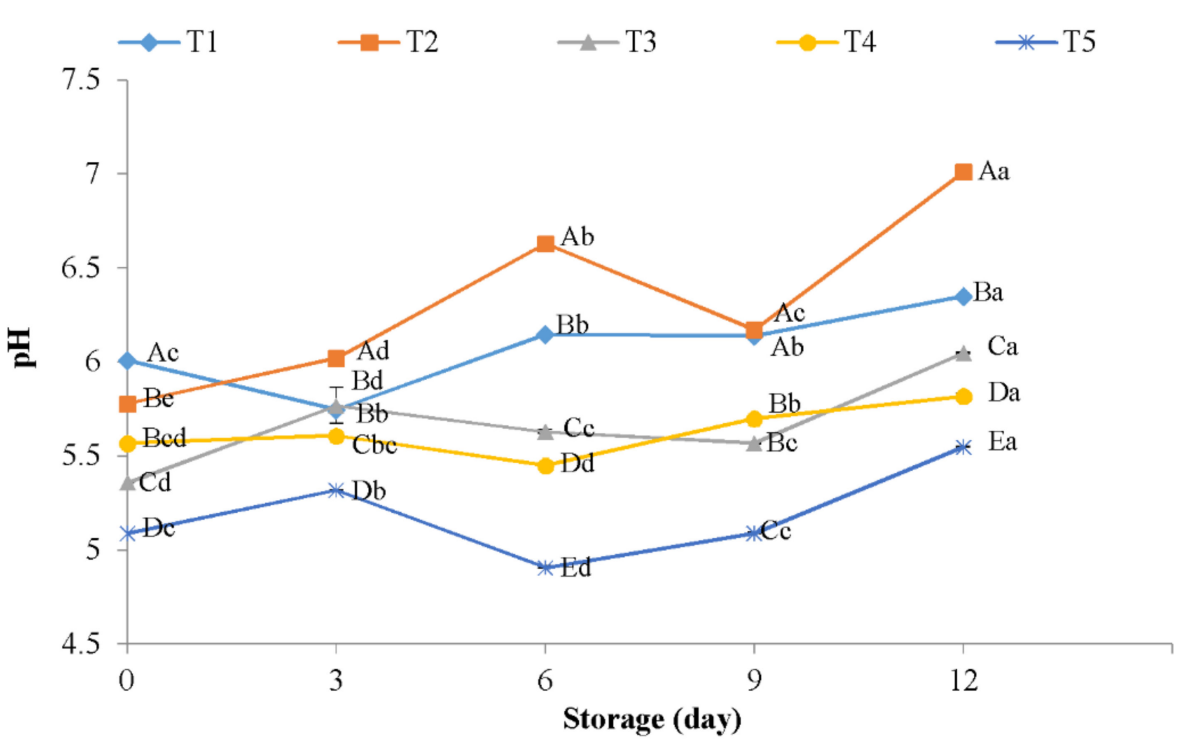

Figure 1. $\mathrm{pH}$ values of chicken meat coated with chitosan containing AFEOs during refrigerated storage. T1: Negative control; T2: Distilled water; T3: 1\% CH coating + 500 ppm AFEOs; T4: $1 \%$ CH coating + 1000 ppm AFEOs; T5: $1 \%$ CH coating + 1500 ppm AFEOs. ${ }^{\text {a-d }}$ Mean values during storage not followed by a common letter differ significantly $(p<0.05)$. ${ }^{\mathrm{A}-\mathrm{E}}$ Mean values among meat samples not followed by a common letter differ significantly $(p<0.05)$.

\subsection{Effect of $C H$-AFEOs Coating on TBARS and TVB-N}

Shelf life and quality attributes of meat and meat products are highly affected by oxidation reactions, particularly lipid and protein [47]. TBARS are used as an important indicator for the measurement of secondary products of oxidation, especially aldehydes, which resulted from the lipid oxidation of polyunsaturated fatty acids [48]. The effects of chitosan-based coating with AFEOs are displayed in Table 3. TBARS values increased continuously during refrigerated storage, being samples coated with chitosan and AFEOs (T4 and T5) those that displayed significantly $(p<0.05)$ lower values at the end of storage (1.61 and 1.64 vs. 1.92 and $2.10 \mathrm{mg} \mathrm{MDA} / \mathrm{kg}$ for T5 and T4, vs. negative control and samples treated with distilled water, respectively). Similar results were reported by Liu et al. [44], who evaluated the impact of chitosan films incorporated with natural preservatives on chilled meat. Jonaidi Jafari et al. [49] studied the effect of chitosan coating with ethanolic extract of propolis on the quality of chicken fillets. The authors reported a less increase of TBARS values in treated samples $(<0.6 \mathrm{mg} \mathrm{MDA} / \mathrm{kg}$ in samples coating with chitosan and $2 \%$ of ethanolic extract of propolis) compared to those observed in control $(>0.8 \mathrm{mg} \mathrm{MDA} / \mathrm{kg})$. These lower TBARS values in coated samples may be 
related to low availableness of oxygen on meat surfaces or chelating impact of chitosan with metal ions [50]. Furthermore, the high antioxidant properties of AFEOs observed by Orhan et al. [28], would also lead to a less increase in TBARS values during storage. Therefore, as expected, chitosan coatings incorporated with AFEOs allowed to extend the shelf life of meat samples by their antioxidative properties. Similar results were observed by Pabast et al. [51] and Fang et al. [52] in lamb meat and fresh pork using chitosan-based coatings with natural antioxidants.

Table 3. Changes in thiobarbituric acid reactive substances (TBARS) and total volatile base nitrogen (TVB-N) values of chicken meat coated with chitosan containing AFEOs during storage at $4{ }^{\circ} \mathrm{C}$.

\begin{tabular}{|c|c|c|c|c|c|c|}
\hline & \multirow{2}{*}{ Sample } & \multicolumn{5}{|c|}{ Storage (Day) } \\
\hline & & $\mathbf{0}$ & 3 & 6 & 9 & 12 \\
\hline \multirow{5}{*}{$\begin{array}{c}\text { TBARS (mg } \\
\text { MDA/kg) }\end{array}$} & $\mathrm{T} 1$ & $1.03 \pm 0.006^{\mathrm{Ae}}$ & $1.16 \pm 0.011^{\mathrm{Bd}}$ & $1.45 \pm 0.017^{\mathrm{Bc}}$ & $1.81 \pm 0.014^{\mathrm{Ab}}$ & $1.92 \pm 0.020^{\mathrm{Ba}}$ \\
\hline & $\mathrm{T} 2$ & $1.03 \pm 0.004^{\mathrm{Ae}}$ & $1.64 \pm 0.017^{\mathrm{Ad}}$ & $1.73 \pm 0.026^{\mathrm{Ac}}$ & $1.87 \pm 0.011^{\mathrm{Ab}}$ & $2.10 \pm 0.007 \mathrm{Aa}$ \\
\hline & T3 & $1.01 \pm 0.003 \mathrm{Ad}$ & $1.10 \pm 0.002^{\mathrm{Bd}}$ & $1.33 \pm 0.029 \mathrm{Cc}$ & $1.62 \pm 0.023 \mathrm{Bb}$ & $1.75 \pm 0.023 \mathrm{Ca}$ \\
\hline & $\mathrm{T} 4$ & $0.98 \pm 0.017^{\mathrm{Ad}}$ & $1.09 \pm 0.001^{\mathrm{Bd}}$ & $1.28 \pm 0.017 \mathrm{Cc}$ & $1.47 \pm 0.026^{\mathrm{Cb}}$ & $1.64 \pm 0.029 \mathrm{Da}$ \\
\hline & $\mathrm{T} 5$ & $0.96 \pm 0.008 \mathrm{Ae}$ & $1.06 \pm 0.006^{\mathrm{Bd}}$ & $1.21 \pm 0.018^{\mathrm{Dc}}$ & $1.41 \pm 0.018^{\mathrm{Cb}}$ & $1.61 \pm 0.020 \mathrm{Da}$ \\
\hline \multirow{5}{*}{$\begin{array}{c}\text { TVB-N } \\
(\mathrm{mg} / 100 \mathrm{~g})\end{array}$} & $\mathrm{T} 1$ & $15.6 \pm 0.001^{\mathrm{Bd}}$ & $36.5 \pm 0.012^{\mathrm{Bc}}$ & $37.2 \pm 0.008^{\mathrm{Bc}}$ & $105.0 \pm 0.004^{\mathrm{Bb}}$ & $151.2 \pm 0.004^{\mathrm{Ba}}$ \\
\hline & $\mathrm{T} 2$ & $17.9 \pm 0.021 \mathrm{Ad}$ & $39.4 \pm 0.003 \mathrm{Ac}$ & $41.9 \pm 0.008^{\mathrm{Ac}}$ & $178.3 \pm 0.008^{\mathrm{Ab}}$ & $182.3 \pm 0.008 \mathrm{Aa}$ \\
\hline & $\mathrm{T} 3$ & $10.0 \pm 0.005^{\mathrm{Cd}}$ & $14.1 \pm 0.004 \mathrm{Cc}$ & $17.1 \pm 0.012 \mathrm{Cb}$ & $18.3 \pm 0.004 \mathrm{Db}$ & $54.3 \pm 0.004 \mathrm{Ca}$ \\
\hline & $\mathrm{T} 4$ & $10.0 \pm 0.004 \mathrm{Ce}$ & $12.8 \pm 0.004^{\mathrm{Dd}}$ & $14.1 \pm 0.004^{\mathrm{Dc}}$ & $19.7 \pm 0.004 \mathrm{Cb}$ & $28.2 \pm 0.004 \mathrm{Da}$ \\
\hline & $\mathrm{T} 5$ & $8.7 \pm 0.009 \mathrm{Dd}$ & $11.1 \pm 0.004^{\mathrm{Ec}}$ & $11.4 \pm 0.006^{\mathrm{Ec}}$ & $18.3 \pm 0.004^{\mathrm{Db}}$ & $25.3 \pm 0.004^{\mathrm{Ea}}$ \\
\hline
\end{tabular}

T1: Negative control; T2: Distilled water; T3: $1 \%$ CH coating + 500 ppm AFEOs; T4: $1 \%$ CH coating + 1000 ppm AFEOs; T5: $1 \%$ $\mathrm{CH}$ coating $+1500 \mathrm{ppm}$ AFEOs. ${ }^{\text {a-e }}$ Mean values in the same row not followed by a common letter differ significantly $(p<0.05)$. ${ }^{A-E}$ Mean values in the same column not followed by a common letter differ significantly $(p<0.05)$.

TVB-N value, which mainly includes amines and ammonia, is one of the most important indicators in meat and meat products shelf life [53]. The TVB-N results of chicken samples during refrigerated time are presented in Table 3. In this study, the initial TVB-N values were between 8.7 and $17.9 \mathrm{mg} / 100 \mathrm{~g}$ for treated samples (T5) and samples treated with distilled water (T2), respectively. These values indicate the allowable situation for applied chicken meat. During storage the TVB-N values in all meat samples increased exponentially, with a rate significantly $(p<0.05)$ higher in untreated samples $(182.3 \mathrm{vs}$. $25.3 \mathrm{mg} / 100 \mathrm{~g}$ for T2 and T5, respectively). According to permitted limit of TVB-N values $(25 \mathrm{mg} / 100 \mathrm{~g})$ in meat and meat products, related to loss of freshness and microbiological contamination, control samples (T1 and T2) exceeded this level on day 3. However, treated samples with $\mathrm{CH}$ and AFEOs can effectively reduce the production of volatile nitrogen bases under acceptability limits until day $9(18.3,19.7$, and $18.3 \mathrm{mg} / 100 \mathrm{~g}$ for samples coated with $\mathrm{CH}$ and 500, 1000, and $1500 \mathrm{ppm}$ of AFEOs, respectively). The results of the present work are in agreement with those found by Mojaddar Langroodi et al. [54]. The authors showed that $\mathrm{CH}$ coating in combination with other natural antioxidants (Sumac extract and Zataria multiflora Boiss oil) could significantly reduce TVB-N formation.

In addition, it can be observed that by increasing the EOs concentration, TVB-N values increased more slowly. At day 12, the coated samples containing $1500 \mathrm{ppm}$ AFEOs displayed significantly lower TVB-N values ( $25.3 \mathrm{vs}$. 28.2 and $54.3 \mathrm{mg} / 100 \mathrm{~g}$ for samples coated with $\mathrm{CH}$ and 500, 1000, and $1500 \mathrm{ppm}$ of AFEOs, respectively). The results of TVB-N values are in paralleled with microbiological results. In fact, the TVB-N results observed among treatments are in agreement with the changes observed in $\mathrm{pH}$, since the antibacterial properties of chitosan and AFEOs could be responsible for the lower $\mathrm{pH}$ values in coated samples. Therefore, the lower microbial growth observed in treated samples would lead to lower TVB-N values [49,55]. 


\subsection{Effect of CH-AFEOs Coating on TPC}

Phenolic compounds, which have potential techno-functional, antioxidant, and antimicrobial properties, are highly present in natural sources like plants extracts and EOs [56]. The effects of chitosan coating in combination with AFEOs on phenolic content of chicken meat are shown in Figure 2. At day 0 of storage, phenolic content in chicken samples coated with chitosan and AFEOs ranged from 30.10 to $41.70 \mathrm{mg} \mathrm{GA} / 100 \mathrm{~g}$, whereas the phenolic content in negative control samples was significantly $(p<0.05)$ lower $(28.20 \mathrm{mg} \mathrm{GA} / 100 \mathrm{~g})$. The highest phenolic content in treated samples is related to the fact that phenolic compounds are one of the main components of EOs [10]. During the storage period, phenolic compounds in all meat samples decreased significantly $(p<0.05)$. However, treated samples continued to be those that showed the highest contents at day 12 , displaying values between 22.20 and $25.20 \mathrm{mg} \mathrm{GA} / 100 \mathrm{~g}$, while negative control and meat treated with distilled water reached to 20 and $20.60 \mathrm{mg} \mathrm{GA} / 100 \mathrm{~g}$, respectively. The decrease in phenolic compounds observed in chicken samples could be attributed to oxidation reactions that take place during storage period [47].

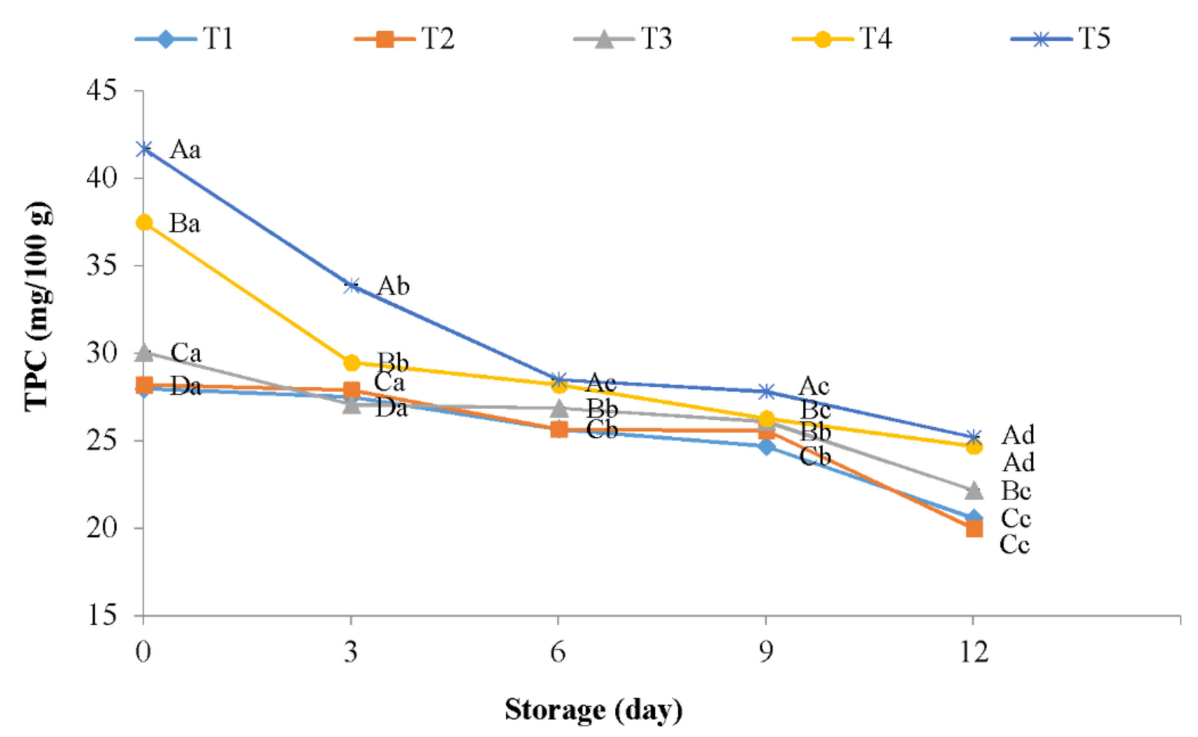

Figure 2. Total phenolic content of chicken meat coated with chitosan containing AFEOs during refrigerated storage. T1: Negative control; T2: Distilled water; T3: 1\% CH coating + 500 ppm AFEOs; T4: $1 \%$ CH coating + 1000 ppm AFEOs; T5: $1 \%$ CH coating +1500 ppm AFEOs. ${ }^{a-d}$ Mean values during storage not followed by a common letter differ significantly $(p<0.05)$. A-D Mean among meat samples not followed by a common letter differ significantly $(p<0.05)$.

Similar results were found with the use of type of coating materials and natural extracts in meat products. In this regard, Alirezalu et al. [20] evaluated the effects of $\varepsilon$ polylysine in combination with natural plant extracts (olive leaves, green tea, and stinging nettle) in frankfurter-type sausage. The authors observed that the samples treated with mixed plant extracts showed significantly higher amounts of phenolic contents compared to control (9.80 vs. $0.07 \mathrm{mg} \mathrm{GA} / 100 \mathrm{~g}$ for treated sausages samples and control samples on day 45 of storage, respectively). Similar results with natural plant extracts (rosemary or Chinese mahogany) in fresh chicken sausage were reported by Liu et al. [33].

\subsection{Effect of CH-AFEOs Coating on Color Parameters}

Color is one of the most important parameters in meat and meat products quality, since its stability could compromise the sensory properties of the product and therefore the consumer acceptance [57]. The color indexes ( $L^{*}$ : Lightness, $a^{*}$ : Redness and $b^{*}$ : Yellowness) of chicken meat samples were significantly $(p<0.05)$ affected by both coating and refrigerated period (Table 4$)$. $\mathrm{L}^{*}$ values of all samples decreased during refrigerated period (Table 4); however, the rate of this reduction was significantly $(p<0.05)$ lower in 
coated samples. The antioxidant and antimicrobial properties of $\mathrm{CH}$ and AFEOs would lead to higher $\mathrm{L}^{*}$ in coated samples. At day 12 , chicken samples coated with $\mathrm{CH}+1500 \mathrm{ppm}$ AFEOs and treated with distilled water showed the highest (36.38) and lowest (25.83) values, respectively. These results are in agreement with those found by Alirezalu et al. [21], who reported a similar trend for lightness in sausages treated with chitosan in combination with other natural antioxidants.

Table 4. Color indexes of chicken meat coated with chitosan containing AFEOs during storage at the $4{ }^{\circ} \mathrm{C}$.

\begin{tabular}{|c|c|c|c|c|c|c|}
\hline & \multirow{2}{*}{ Sample } & \multicolumn{5}{|c|}{ Storage (Day) } \\
\hline & & $\mathbf{0}$ & 3 & 6 & 9 & 12 \\
\hline \multirow{5}{*}{$L^{*}$} & $\mathrm{~T} 1$ & $30.94 \pm 0.618^{\mathrm{Ca}}$ & $26.94 \pm 0.529 \mathrm{Bb}$ & $27.77 \pm 0.309 \mathrm{Bb}$ & $27.44 \pm 0.277^{\mathrm{Cb}}$ & $27.00 \pm 0.600^{\mathrm{Bb}}$ \\
\hline & $\mathrm{T} 2$ & $31.11 \pm 0.493^{\mathrm{Ca}}$ & $33.00 \pm 0.003^{\mathrm{Aa}}$ & $29.16 \pm 0.254^{\mathrm{Ba}}$ & $33.22 \pm 0.309 \mathrm{Ba}$ & $25.83 \pm 0.984^{\mathrm{Bb}}$ \\
\hline & T3 & $38.61 \pm 0.111^{\mathrm{Ba}}$ & $34.33 \pm 0.346^{\mathrm{Ab}}$ & $37.11 \pm 0.829$ Аа & $33.72 \pm 0.364 \mathrm{ABb}$ & $37.05 \pm 0.242 \mathrm{Aa}$ \\
\hline & $\mathrm{T} 4$ & $38.83 \pm 0.346$ Аа & $35.50 \pm 0.010 \mathrm{Aab}$ & $36.77 \pm 0.547 \mathrm{Aa}$ & $32.11 \pm 0.618^{\mathrm{Bb}}$ & $38.05 \pm 0.388^{\mathrm{Aa}}$ \\
\hline & $\mathrm{T} 5$ & $37.93 \pm 0.693 \mathrm{Aa}$ & $34.44 \pm 0.433^{\mathrm{Ab}}$ & $30.44 \pm 0.454^{\mathrm{Bc}}$ & $36.59 \pm 0.746^{\mathrm{Aa}}$ & $36.38 \pm 0.484^{\mathrm{Aa}}$ \\
\hline \multirow{5}{*}{$a^{*}$} & $\mathrm{~T} 1$ & $0.66 \pm 0.166^{\mathrm{ABb}}$ & $4.94 \pm 0.444 \mathrm{Aa}$ & $-0.22 \pm 0.400 \mathrm{Aab}$ & $-2.00 \pm 0.384^{\mathrm{Ab}}$ & $-5.33 \pm 0.509 \mathrm{Ac}$ \\
\hline & $\mathrm{T} 2$ & $-1.33 \pm 0.254^{\mathrm{BCb}}$ & $2.88 \pm 0.200 \mathrm{Aa}$ & $-3.77 \pm 0.388^{\mathrm{Bc}}$ & $-3.83 \pm 0.166^{C c}$ & $-4.22 \pm 0.337^{C d}$ \\
\hline & $\mathrm{T} 3$ & $-3.50 \pm 0.096^{\mathrm{Ca}}$ & $-3.33 \pm 0.096^{\mathrm{Ca}}$ & $-3.94 \pm 0.293^{\mathrm{Bb}}$ & $-4.72 \pm 0.242^{\mathrm{Dc}}$ & $-4.77 \pm 0.400^{\mathrm{Bc}}$ \\
\hline & $\mathrm{T} 4$ & $-2.38 \pm 0.995 \mathrm{Ca}$ & $-4.11 \pm 0.364^{\mathrm{Cb}}$ & $-4.94 \pm 0.474^{\mathrm{Cd}}$ & $-2.27 \pm 0.293^{\mathrm{Ba}}$ & $-4.83 \pm 0.096^{\mathrm{Bc}}$ \\
\hline & $\mathrm{T} 5$ & $1.46 \pm 0.062 \mathrm{Aa}$ & $-1.88 \pm 0.493 \mathrm{Bc}$ & $-0.77 \pm 0.146^{\mathrm{Ab}}$ & $-1.68 \pm 0.168$ Ac & $-4.33 \pm 0.509 \mathrm{Cd}$ \\
\hline \multirow{5}{*}{$b^{*}$} & $\mathrm{~T} 1$ & $19.11 \pm 0.963^{\mathrm{Cbc}}$ & $18.94 \pm 0.146^{\mathrm{Cc}}$ & $17.94 \pm 0.111^{\mathrm{Cd}}$ & $16.11 \pm 0.200 \mathrm{Ce}$ & $20.38 \pm 0.146^{\mathrm{Ca}}$ \\
\hline & $\mathrm{T} 2$ & $17.83 \pm 0.146^{\mathrm{Dd}}$ & $20.00 \pm 0.192^{\mathrm{Cb}}$ & $17.87 \pm 0.055^{\mathrm{Cd}}$ & $18.16 \pm 0.192 \mathrm{Bc}$ & $22.22 \pm 0.585^{\mathrm{Ba}}$ \\
\hline & $\mathrm{T} 3$ & $17.16 \pm 0.254^{\mathrm{Dd}}$ & $22.83 \pm 0.166^{\mathrm{Ab}}$ & $21.61 \pm 0.493 \mathrm{ABc}$ & $21.11 \pm 0.055^{\mathrm{Ac}}$ & $24.83 \pm 0.333^{\mathrm{Aa}}$ \\
\hline & $\mathrm{T} 4$ & $20.83 \pm 0.192^{\mathrm{BCb}}$ & $21.61 \pm 0.111 \mathrm{ABa}$ & $22.11 \pm 0.200 \mathrm{Aa}$ & $20.33 \pm 0.192 \mathrm{Ab}$ & $22.22 \pm 0.222 \mathrm{Ba}$ \\
\hline & $\mathrm{T} 5$ & $23.33 \pm 0.461$ Аа & $20.27 \pm 0.293^{\mathrm{Bb}}$ & $20.44 \pm 0.146^{\mathrm{Bb}}$ & $19.26 \pm 0.156^{\mathrm{ABb}}$ & $23.66 \pm 0.288 \mathrm{ABa}$ \\
\hline
\end{tabular}

T1: Negative control; T2: Distilled water; T3: 1\% CH coating + 500 ppm AFEOs; T4: 1\% CH coating + 1000 ppm AFEOs; T5: 1\% $\mathrm{CH}$ coating +1500 ppm AFEOs. ${ }^{\text {a-e }}$ Mean values in the same row not followed by a common letter differ significantly $(p<0.05)$. ${ }^{\mathrm{A}-\mathrm{D}}$ Mean values in the same column not followed by a common letter differ significantly $(p<0.05)$.

All meat samples revealed a reduction in $\mathrm{a}^{*}$ during refrigerated period. The formation of free radicals from lipid oxidation and met-myoglobin may be the main reasons for the reduction of $a^{*}$ values $[14,58]$. Higher $a^{*}$ values were observed in coated samples compared to those found in negative control, which as mentioned above may be due to the high antioxidant properties of $\mathrm{CH}$ and AFEOs. A similar trend in the reduction of $\mathrm{a}^{*}$ value in lamb burgers treated with natural extracts was reported by De Carvalho et al. [40].

Regarding yellowness, this parameter is highly affected by the enzymatic browning reactions that occur during the refrigerated storage of meat samples [59]. However, samples coated with $\mathrm{CH}$ and high concentration of AFEOs showed significantly $(p<0.05)$ higher $\mathrm{b}^{*}$ values than those found by negative control samples at the end of storage (23.66 vs. 20.38 for $\mathrm{T} 5$ and $\mathrm{T} 1$, respectively).

\subsection{Effect of CH-AFEOs Coating on Microbiological Analysis}

The results of TVC, coliform, molds, and yeasts are shown at Table 5. At day 0, TVC counts in treated samples ranged between 2.27 and $2.33 \mathrm{Log}$ CFU/g, which is significantly lower than those obtained for negative control (4.48 Log CFU/g). These initial bacterial numbers reflect the high antimicrobial properties associated with the use of $\mathrm{CH}$ coating and AFEOs in meat samples. Chitosan coating containing AFEOs led to approximately $3 \mathrm{Log}$ CFU/g reduction in TVC from those obtained by control. Increase in the thickness of the chitosan coating not only have inhibitory effects against microbial growth but also could maintain the quality and stability of samples. However, it had been proved that $1 \%$ chitosan could also have efficient impacts on meat quality and shelf life. Considering the acceptable limitations of TVC counts (6 Log CFU/g) in fresh poultry meat $[60,61]$, the samples coated with $\mathrm{CH}$ in combination with the highest dose of AFEOs displayed acceptable levels at the end of storage time (Table 5), which reflects the possibility of using 
this coating to extend the shelf life of a highly perishable product, such as fresh chicken meat, ensuring its safety. The results of the present study are in agreement with those found by Jonaidi Jafari et al. [49] on chicken fillets coated with chitosan and ethanolic propolis extract. Bazargani-Gilani et al. [62] also evaluated the effects of chitosan edible coating with plant EOs on chicken breast meat, also reporting the possibility of using the combination of chitosan and EOS to extend the storage time by 10 or 15 days the storage time, which are in agreement with the results found in the present work. Cationic property of chitosan allows to electrostatic interaction between NH3 group (as a positive charges) on of the glucosamine monomer in chitosan molecules and microbial cell membrane (negative charges) led to the leakage of intracellular components could be the reason of antimicrobial properties of chitosan coating, which has been described by Duan et al. [63]. In the other hand, the selective permeability of chitosan [58], which decrease the oxygen transfer to the meat and meat products might be the main reason of extended stability and shelf life.

Table 5. Evaluation of microbiological counts (Log CFU/g) in chicken meat coated with chitosan containing AFEOs during storage at $4{ }^{\circ} \mathrm{C}$.

\begin{tabular}{|c|c|c|c|c|c|c|}
\hline & \multirow{2}{*}{ Sample } & \multicolumn{5}{|c|}{ Storage (Day) } \\
\hline & & 0 & 3 & 6 & 9 & 12 \\
\hline \multirow{5}{*}{ TVC } & $\mathrm{T} 1$ & $4.48 \pm 0.012 \mathrm{Ac}$ & $5.89 \pm 0.196^{\mathrm{Bb}}$ & $7.77 \pm 0.004^{\mathrm{Aa}}$ & $7.95 \pm 0.001 \mathrm{Aa}$ & $8.01 \pm 0.012 \mathrm{Aa}$ \\
\hline & $\mathrm{T} 2$ & $4.47 \pm 0.115^{\mathrm{Ac}}$ & $6.22 \pm 0.114^{\mathrm{Ab}}$ & $8.04 \pm 0.022 \mathrm{Aa}$ & $8.13 \pm 0.020^{\mathrm{Aa}}$ & $8.21 \pm 0.015^{\mathrm{Aa}}$ \\
\hline & $\mathrm{T} 3$ & $2.29 \pm 0.013^{\mathrm{Be}}$ & $3.02 \pm 0.026^{\mathrm{Cd}}$ & $4.42 \pm 0.018^{\mathrm{Bc}}$ & $5.67 \pm 0.005^{\mathrm{Bb}}$ & $7.41 \pm 0.012^{\mathrm{Ba}}$ \\
\hline & $\mathrm{T} 4$ & $2.33 \pm 0.032 \mathrm{Be}$ & $2.85 \pm 0.009 \mathrm{Cd}$ & $3.45 \pm 0.017^{\mathrm{Cc}}$ & $5.55 \pm 0.008^{\mathrm{Bb}}$ & $6.90 \pm 0.027^{\mathrm{Ca}}$ \\
\hline & $\mathrm{T} 5$ & $2.27 \pm 0.015^{\mathrm{Bd}}$ & $2.30 \pm 0.007^{\mathrm{Dd}}$ & $3.27 \pm 0.013^{C c}$ & $4.61 \pm 0.010^{\mathrm{Cb}}$ & $5.32 \pm 0.014^{\mathrm{Da}}$ \\
\hline \multirow{5}{*}{ Coliforms } & $\mathrm{T} 1$ & $4.21 \pm 0.132 \mathrm{Ad}$ & $4.71 \pm 0.052^{\mathrm{Bc}}$ & $7.82 \pm 0.009 \mathrm{Ab}$ & $8.05 \pm 0.014^{\mathrm{Ab}}$ & $8.58 \pm 0.019 \mathrm{Aa}$ \\
\hline & $\mathrm{T} 2$ & $4.08 \pm 0.044^{\mathrm{Ad}}$ & $6.18 \pm 0.006^{\mathrm{Ac}}$ & $8.23 \pm 0.012^{\mathrm{Ab}}$ & $8.38 \pm 0.005^{\mathrm{Ab}}$ & $8.84 \pm 0.004^{\mathrm{Aa}}$ \\
\hline & $\mathrm{T} 3$ & $1.47 \pm 0.013^{\mathrm{Bc}}$ & $1.31 \pm 0.318^{\mathrm{Dc}}$ & $3.33 \pm 0.017^{\mathrm{Bb}}$ & $3.64 \pm 0.028^{\mathrm{Bb}}$ & $4.47 \pm 0.004^{\mathrm{Ba}}$ \\
\hline & $\mathrm{T} 4$ & ND & $1.78 \pm 0.015^{C d}$ & $3.12 \pm 0.067^{\mathrm{BC}}$ & $3.50 \pm 0.046^{\mathrm{Bb}}$ & $4.18 \pm 0.009^{\mathrm{BCa}}$ \\
\hline & $\mathrm{T} 5$ & ND & $1.47 \pm 0.012^{\mathrm{Dd}}$ & $2.86 \pm 0.019 \mathrm{Cc}^{\mathrm{C}}$ & $3.03 \pm 0.009 \mathrm{Cb}$ & $3.87 \pm 0.031 \mathrm{Ca}$ \\
\hline \multirow{5}{*}{ Molds and yeast } & $\mathrm{T} 1$ & $3.34 \pm 0.022 \mathrm{Be}$ & $3.68 \pm 0.046^{\mathrm{Bd}}$ & $6.03 \pm 0.004^{\mathrm{Bc}}$ & $7.28 \pm 0.011^{\mathrm{Bb}}$ & $7.55 \pm 0.015^{\mathrm{Ba}}$ \\
\hline & $\mathrm{T} 2$ & $3.66 \pm 0.029 \mathrm{Ae}$ & $4.13 \pm 0.025 \mathrm{Ad}$ & $6.96 \pm 0.006^{\mathrm{Ac}}$ & $7.78 \pm 0.012 \mathrm{Ab}$ & $8.02 \pm 0.020 \mathrm{Aa}$ \\
\hline & $\mathrm{T} 3$ & $1.60 \pm 0.012 \mathrm{Ce}$ & $1.94 \pm 0.013^{\mathrm{Cd}}$ & $3.97 \pm 0.023{ }^{C c}$ & $4.59 \pm 0.007^{\mathrm{Cb}}$ & $4.92 \pm 0.026^{\mathrm{Ca}}$ \\
\hline & $\mathrm{T} 4$ & $1.30 \pm 0.013^{\mathrm{De}}$ & $1.84 \pm 0.012 \mathrm{Cd}$ & $3.49 \pm 0.057^{\mathrm{Dc}}$ & $4.38 \pm 0.046^{\mathrm{Db}}$ & $4.61 \pm 0.013^{\mathrm{Da}}$ \\
\hline & $\mathrm{T} 5$ & $1.00 \pm 0.015^{\mathrm{Ee}}$ & $1.69 \pm 0.015^{\mathrm{Dd}}$ & $2.99 \pm 0.025^{\mathrm{Ec}}$ & $3.97 \pm 0.022 \mathrm{~Eb}$ & $4.27 \pm 0.015^{\mathrm{Ea}}$ \\
\hline
\end{tabular}

T1: Negative control; T2: Distilled water; T3: 1\% CH coating + 500 ppm AFEOs; T4: 1\% CH coating + 1000 ppm AFEOs; T5: 1\% CH coating +1500 ppm AFEOs. ND: Not detected. ${ }^{\text {a-e }}$ Mean values in the same row not followed by a common letter differ significantly $(p<0.05) .{ }^{\text {A-E }}$ Mean values in the same column not followed by a common letter differ significantly $(p<0.05)$.

The meat and meat products surfaces are highly susceptible for molds and yeasts growth, which can lead to spoilage and negative impacts on safety and organoleptic attributes. The chicken meat samples coated with $\mathrm{CH}+1500$ ppm AFEOs displayed significantly $(p<0.05)$ higher inhibitory effects against molds and yeasts during storage. At the beginning of storage, molds, and yeasts ranged between 1.0 and $3.66 \mathrm{Log} \mathrm{CFU} / \mathrm{g}$ for samples coated with $\mathrm{CH}+1500 \mathrm{ppm}$ AFEOs and distilled water, respectively, which increased significantly $(p<0.05)$ reaching values between 4.27 and $8.02 \mathrm{Log}$ CFU/g at day 12 , respectively. In the case of coliforms, a group of microorganisms known as hygienic quality indicators in meat and meat products [64], the counts increased during storage. The rate of this increase was significantly $(p<0.05)$ lower in coated samples with $\mathrm{CH}+\mathrm{AFEOs}$ (especially in $1500 \mathrm{ppm}$ AFEOs), displaying values after 12 days of storage of 3.87 Log CFU/g compared to values of 8.58 and $8.84 \mathrm{Log}$ CFU/g observed in negative control samples.

To sum up, $\mathrm{CH}$ coating + $1500 \mathrm{ppm}$ AFEOs showed the highest antimicrobial activities against TVC, coliforms, molds, and yeasts. The results of present work are in agreement with those reported by Alirezalu et al. [21], who support the use of chitosan (1\%) in combination with plant extracts as antimicrobial ingredients in frankfurter-type sausage. 
Similar results were obtained by Berizi et al. [46] with the combination of chitosan edible coating and pomegranate peel extract.

\subsection{Effect of CH-AFEOs Coating on Sensory Properties}

The effects of $\mathrm{CH}$ coating with AFEOs on organoleptic properties of meat samples are illustrated in Figure $3 a, b$. The results observed on day 0 showed that coated meat samples with $\mathrm{CH}$ and AFEOs had a negatively effect on sensory attributes. Despite at the beginning of storage, the highest and lowest sensory scores were for negative control and $\mathrm{CH}$ containing $500 \mathrm{ppm}$ AFEOs, and the scores changed as storage progressed since the samples coated with $\mathrm{CH}$ and AFEOs displayed significantly $(p<0.05)$ higher scores in all of the attributes evaluated. This could be associated with the higher microbial growth and oxidation reactions that occur in negative control, resulting in a sharply decrease during storage of its sensory properties in comparison with coated samples. Again, the results showed that samples coated with $\mathrm{CH}+1500 \mathrm{ppm}$ AFEOs displayed the best results, so this coating could significantly preserve sensory attributes of fresh chicken meat during storage. These results corroborate those previously found by Kanatt et al. [65], who reported that $\mathrm{CH}$ coating has no negative effects on organoleptic characteristics of meat and meat products. Furthermore, similar results were previously found by Petrou et al. [66] in chicken breast meat coated with chitosan and oregano oil.

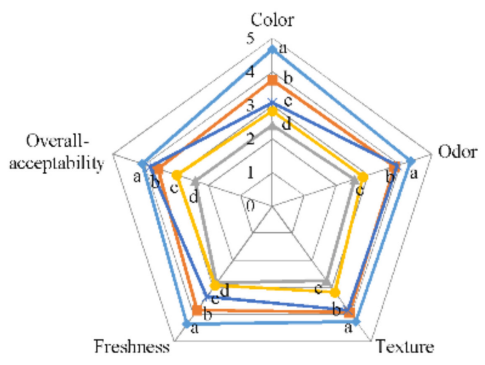

(a)

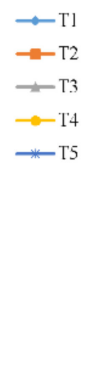

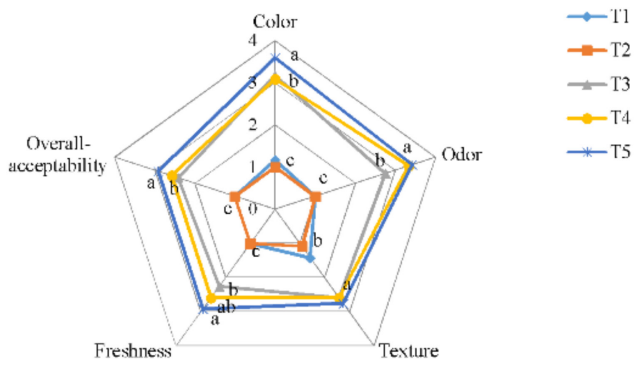

(b)

Figure 3. Sensory properties of chicken meat coated with chitosan containing AFEOs at day 0 (a) and day 9 (b) during storage at $4{ }^{\circ} \mathrm{C}$. T1: Negative control; T2: Distilled water; T3: $1 \% \mathrm{CH}$ coating $+500 \mathrm{ppm}$ AFEOs; T4: $1 \% \mathrm{CH}$ coating $+1000 \mathrm{ppm}$ AFEOs; T5: $1 \% \mathrm{CH}$ coating +1500 ppm AFEOs. ${ }^{a-d}$ Mean values among meat samples not followed by a common letter differ significantly $(p<0.05)$.

\section{Conclusions}

The results of the current research revealed that chitosan-based coatings with AFEOs allow deceleration of the microbial growth and the undesirable chemical reactions that occur in meat during storage and, therefore, can extend the shelf life of chicken fillets. The presence of natural antioxidant and antimicrobial components in the composition of AFEOs and chitosan are the main responsible for these characteristics. Coated samples remained within acceptable range of quality-chemical factors, such as TBARS, TVB-N, and $\mathrm{pH}$, for longer time. The outcomes of this study showed that coating based chitosan with $1500 \mathrm{ppm}$ AFEOs had the best inhibitory effects on the oxidative activity and microbial growth. The results also revealed that chitosan coating incorporated with $1500 \mathrm{ppm}$ AFEOs can significantly prolong the stability of chicken breast meat and could be suggested as potential coating materials in meat and meat products.

Author Contributions: Conceptualization, K.A. and J.M.L.; writing-original draft preparation, A.A. and Z.N.; writing-review and editing, M.Y., K.A., M.P., and J.M.L. All authors have read and agreed to the published version of the manuscript.

Funding: This research received no external funding.

Institutional Review Board Statement: Not applicable. 
Informed Consent Statement: Not applicable.

Data Availability Statement: The data presented in this study are available on request from the corresponding author.

Acknowledgments: Thanks to GAIN (Axencia Galega de Innovación) for supporting this work (grant number IN607A2019/01). José M. Lorenzo and Mirian Pateiro are members of the Healthy Meat network, funded by CYTED (ref. 119RT0568).

Conflicts of Interest: The authors declare no conflict of interest.

\section{References}

1. Noori, S.; Zeynali, F.; Almasi, H. Antimicrobial and antioxidant efficiency of nanoemulsion-based edible coating containing ginger (Zingiber officinale) essential oil and its effect on safety and quality attributes of chicken breast fillets. Food Control 2018, 84, 312-320. [CrossRef]

2. Latou, E.; Mexis, S.F.; Badeka, A.V.; Kontakos, S.; Kontominas, M.G. Combined effect of chitosan and modified atmosphere packaging for shelf life extension of chicken breast fillets. LWT Food Sci. Technol. 2014, 55, 263-268. [CrossRef]

3. Lorenzo, J.M.; Batlle, R.; Gómez, M. Extension of the shelf-life of foal meat with two antioxidant active packaging systems. LWT Food Sci. Technol. 2014, 59, 181-188. [CrossRef]

4. Woraprayote, W.; Malila, Y.; Sorapukdee, S.; Swetwiwathana, A.; Benjakul, S.; Visessanguan, W. Bacteriocins from lactic acid bacteria and their applications in meat and meat products. Meat Sci. 2016, 120, 118-132. [CrossRef]

5. Lorenzo, J.M.; Munekata, P.E.S.; Gómez, B.; Barba, F.J.; Mora, L.; Pérez-Santaescolástica, C.; Toldrá, F. Bioactive peptides as natural antioxidants in food products-A review. Trends Food Sci. Technol. 2018, 79, 136-147. [CrossRef]

6. Mexis, S.F.; Chouliara, E.; Kontominas, M.G. Shelf life extension of ground chicken meat using an oxygen absorber and a citrus extract. LWT Food Sci. Technol. 2012, 49, 21-27. [CrossRef]

7. Simona, J.; Dani, D.; Petr, S.; Marcela, N.; Jakub, T.; Bohuslava, T. Edible films from carrageenan/orange essential oil/trehalosestructure, optical properties, and antimicrobial activity. Polymers 2021, 13, 332-351. [CrossRef] [PubMed]

8. Alirezalu, K.; Hesari, J.; Eskandari, M.H.; Valizadeh, H.; Sirousazar, M. Effect of Green Tea, Stinging Nettle and Olive Leaves Extracts on the Quality and Shelf Life Stability of Frankfurter Type Sausage. J. Food Process. Preserv. 2017, 41, e13100. [CrossRef]

9. Lin, L.; Gu, Y.; Sun, Y.; Cui, H. Characterization of chrysanthemum essential oil triple-layer liposomes and its application against Campylobacter jejuni on chicken. LWT 2019, 107, 16-24. [CrossRef]

10. Pateiro, M.; Barba, F.J.; Domínguez, R.; Sant'Ana, A.S.; Mousavi Khaneghah, A.; Gavahian, M.; Gómez, B.; Lorenzo, J.M. Essential oils as natural additives to prevent oxidation reactions in meat and meat products: A review. Food Res. Int. 2018, 113, 156-166. [CrossRef]

11. Alirezalu, A.; Ahmadi, N.; Salehi, P.; Sonboli, A.; Alirezalu, K.; Mousavi Khaneghah, A.; Barba, F.J.; Munekata, P.E.S.; Lorenzo, J.M. Physicochemical Characterization, Antioxidant Activity, and Phenolic Compounds of Hawthorn (Crataegus spp.) Fruits Species for Potential Use in Food Applications. Foods 2020, 9, 436. [CrossRef]

12. Lorenzo, J.M.; Munekata, P.E.S. Phenolic compounds of green tea: Health benefits and technological application in food. Asian Pac. J. Trop. Biomed. 2016, 6, 709-719. [CrossRef]

13. Umaraw, P.; Munekata, P.E.S.; Verma, A.K.; Barba, F.J.; Singh, V.P.; Kumar, P.; Lorenzo, J.M. Edible films/coating with tailored properties for active packaging of meat, fish and derived products. Trends Food Sci. Technol. 2020, 98, 10-24. [CrossRef]

14. Lorenzo, J.M.J.M.; Sineiro, J.; Amado, I.R.; Franco, D. Influence of natural extracts on the shelf life of modified atmospherepackaged pork patties. Meat Sci. 2014, 96, 526-534. [CrossRef]

15. Domínguez, R.; Barba, F.J.; Gómez, B.; Putnik, P.; Bursać Kovačević, D.; Pateiro, M.; Santos, E.M.; Lorenzo, J.M. Active packaging films with natural antioxidants to be used in meat industry: A review. Food Res. Int. 2018, 113, 93-101. [CrossRef] [PubMed]

16. Mulla, M.; Ahmed, J.; Al-Attar, H.; Castro-Aguirre, E.; Arfat, Y.A.; Auras, R. Antimicrobial efficacy of clove essential oil infused into chemically modified LLDPE film for chicken meat packaging. Food Control 2017, 73, 663-671. [CrossRef]

17. Hashemi, S.M.B.; Mousavi Khaneghah, A. Characterization of novel basil-seed gum active edible films and coatings containing oregano essential oil. Prog. Org. Coatings 2017, 110, 35-41. [CrossRef]

18. Cui, H.; Wu, J.; Li, C.; Lin, L. Improving anti-listeria activity of cheese packaging via nanofiber containing nisin-loaded nanoparticles. LWT Food Sci. Technol. 2017, 81, 233-242. [CrossRef]

19. Lin, L.; Xue, L.; Duraiarasan, S.; Haiying, C. Preparation of $\varepsilon$-polylysine/chitosan nanofibers for food packaging against Salmonella on chicken. Food Packag. Shelf Life 2018, 17, 134-141. [CrossRef]

20. Alirezalu, K.; Hesari, J.; Yaghoubi, M.; Khaneghah, A.M.; Alirezalu, A.; Pateiro, M.; Lorenzo, J.M. Combined effects of $\varepsilon$-polylysine and $\varepsilon$-polylysine nanoparticles with plant extracts on the shelf life and quality characteristics of nitrite-free frankfurter-type sausages. Meat Sci. 2021, 172, 108318. [CrossRef]

21. Alirezalu, K.; Hesari, J.; Nemati, Z.; Munekata, P.E.S.; Barba, F.J.; Lorenzo, J.M. Combined effect of natural antioxidants and antimicrobial compounds during refrigerated storage of nitrite-free frankfurter-type sausage. Food Res. Int. 2019, 120, 839-850. [CrossRef] 
22. Farajzadeh, F.; Motamedzadegan, A.; Shahidi, S.A.; Hamzeh, S. The effect of chitosan-gelatin coating on the quality of shrimp (Litopenaeus vannamei) under refrigerated condition. Food Control 2016, 67, 163-170. [CrossRef]

23. Mehdizadeh, T.; Tajik, H.; Langroodi, A.M.; Molaei, R.; Mahmoudian, A. Chitosan-starch film containing pomegranate peel extract and Thymus kotschyanus essential oil can prolong the shelf life of beef. Meat Sci. 2020, 163, 108073. [CrossRef] [PubMed]

24. Mehdizadeh, T.; Mojaddar Langroodi, A. Chitosan coatings incorporated with propolis extract and Zataria multiflora Boiss oil for active packaging of chicken breast meat. Int. J. Biol. Macromol. 2019, 141, 401-409. [CrossRef] [PubMed]

25. Zhang, H.; Liang, Y.; Li, X.; Kang, H. Effect of chitosan-gelatin coating containing nano-encapsulated tarragon essential oil on the preservation of pork slices. Meat Sci. 2020, 166, 108137. [CrossRef] [PubMed]

26. Liu, T.; Liu, L.; Gong, X.; Chi, F.; Ma, Z. Fabrication and comparison of active films from chitosan incorporating different spice extracts for shelf life extension of refrigerated pork. LWT 2021, 135, 110181. [CrossRef]

27. Bora, K.S.; Sharma, A. The Genus Artemisia: A Comprehensive Review. Pharm. Biol. 2011, 49, 101-109. [CrossRef]

28. Orhan, I.E.; Belhattab, R.; Şenol, F.S.; Gülpinar, A.R.; Hoşbaş, S.; Kartal, M. Profiling of cholinesterase inhibitory and antioxidant activities of Artemisia absinthium, A. herba-alba, A. fragrans, Marrubium vulgare, M. astranicum, Origanum vulgare subsp. glandulossum and essential oil analysis of two Artemisia species. Ind. Crops Prod. 2010, 32, 566-571. [CrossRef]

29. Baldino, L.; Reverchon, E.; Della Porta, G. An optimized process for $\mathrm{SC}_{-} \mathrm{CO}_{2}$ extraction of antimalarial compounds from Artemisia annua L. J. Supercrit Fluids 2017, 128, 89-93. [CrossRef]

30. Wan, X.L.; Song, Z.H.; Niu, Y.; Cheng, K.; Zhang, J.F.; Ahmad, H.; Zhang, L.L.; Wang, T. Evaluation of enzymatically treated Artemisia annua L. on growth performance, meat quality, and oxidative stability of breast and thigh muscles in broilers. Poult. Sci. 2017, 96, 844-850. [CrossRef]

31. Kim, C.H.; Kim, G.B.; Chang, M.B.; Bae, G.S.; Paik, I.K.; Kil, D.Y. Effect of dietary supplementation of Lactobacillus-fermented Artemisia princeps on growth performance, meat lipid peroxidation, and intestinal microflora in Hy-line Brown male chickens. Poult. Sci. 2012, 91, 2845-2851. [CrossRef] [PubMed]

32. Karsli, B.; Caglak, E.; Prinyawiwatkul, W. Effect of high molecular weight chitosan coating on quality and shelf life of refrigerated channel catfish fillets. LWT Food Sci. Technol. 2021, 142, 111034. [CrossRef]

33. Liu, D.C.; Tsau, R.T.; Lin, Y.C.; Jan, S.S.; Tan, F.J. Effect of various levels of rosemary or Chinese mahogany on the quality of fresh chicken sausage during refrigerated storage. Food Chem. 2009, 117, 106-113. [CrossRef]

34. Goulas, A.E.; Kontominas, M.G. Effect of salting and smoking-method on the keeping quality of chub mackerel (Scomber japonicus): Biochemical and sensory attributes. Food Chem. 2005, 93, 511-520. [CrossRef]

35. León, K.; Mery, D.; Pedreschi, F.; León, J. Color measurement in L*a*b* units from RGB digital images. Food Res. Int. 2006, 39, 1084-1091. [CrossRef]

36. FDA. Bacteriological Analytical Manual for Foods; US Government Printing Office: Washington, DC, USA, 2013.

37. Economou, T.; Pournis, N.; Ntzimani, A.; Savvaidis, I.N. Nisin-EDTA treatments and modified atmosphere packaging to increase fresh chicken meat shelf-life. Food Chem. 2009, 114, 1470-1476. [CrossRef]

38. Gahruie, H.H.; Ziaee, E.; Eskandari, M.H.; Hosseini, S.M.H. Characterization of basil seed gum -based edible films incorporated with Zataria multiflora essential oil nanoemulsion. Carbohydr. Polym. 2017, 166, 93-103. [CrossRef]

39. Agregán, R.; Barba, F.J.; Gavahian, M.; Franco, D.; Khaneghah, A.M.; Carballo, J.; Ferreira, I.C.F.R.C.; da Silva Barretto, A.C.; Lorenzo, J.M.; Silva Barretto, A.C.; et al. Fucus vesiculosus extracts as natural antioxidants for improvement of physicochemical properties and shelf life of pork patties formulated with oleogels. J. Sci. Food Agric. 2019, 99, 4561-4570. [CrossRef]

40. De Carvalho, F.A.L.; Lorenzo, J.M.; Pateiro, M.; Bermúdez, R.; Purriños, L.; Trindade, M.A. Effect of guarana (Paullinia cupana) seed and pitanga (Eugenia uniflora L.) leaf extracts on lamb burgers with fat replacement by chia oil emulsion during shelf life storage at $2{ }^{\circ} \mathrm{C}$. Food Res. Int. 2019, 125, 108554. [CrossRef] [PubMed]

41. Cullere, M.; Dalle Zotte, A.; Tasoniero, G.; Giaccone, V.; Szendrő, Z.; Szín, M.; Odermatt, M.; Gerencsér, Z.; Dal Bosco, A.; Matics, Z. Effect of diet and packaging system on the microbial status, $\mathrm{pH}$, color and sensory traits of rabbit meat evaluated during chilled storage. Meat Sci. 2018, 141, 36-43. [CrossRef]

42. Alirezalu, K.; Shafaghi Molan, H.; Yaghoubi, M.; Pateiro, M.; Lorenzo, J.M. $\varepsilon$-polylysine coating with stinging nettle extract for fresh beef preservation. Meat Sci. 2021. [CrossRef]

43. Radha Krishnan, K.; Babuskin, S.; Azhagu Saravana Babu, P.; Sasikala, M.; Sabina, K.; Archana, G.; Sivarajan, M.; Sukumar, M. Antimicrobial and antioxidant effects of spice extracts on the shelf life extension of raw chicken meat. Int. J. Food Microbiol. 2014, 171, 32-40. [CrossRef] [PubMed]

44. Liu, F.; Chang, W.; Chen, M.; Xu, F.; Ma, J.; Zhong, F. Tailoring physicochemical properties of chitosan films and their protective effects on meat by varying drying temperature. Carbohydr. Polym. 2019, 212, 150-159. [CrossRef]

45. Vaithiyanathan, S.; Naveena, B.M.; Muthukumar, M.; Girish, P.S.; Kondaiah, N. Effect of dipping in pomegranate (Punica granatum) fruit juice phenolic solution on the shelf life of chicken meat under refrigerated storage $\left(4^{\circ} \mathrm{C}\right)$. Meat Sci. 2011, 88 , 409-414. [CrossRef]

46. Berizi, E.; Hosseinzadeh, S.; Shekarforoush, S.S.; Barbieri, G. Microbial, chemical, textural and sensory properties of coated rainbow trout by chitosan combined with pomegranate peel extract during frozen storage. Int. J. Biol. Macromol. 2018, 106, 1004-1013. [CrossRef] [PubMed]

47. Domínguez, R.; Pateiro, M.; Gagaoua, M.; Barba, F.J.; Zhang, W.; Lorenzo, J.M. A comprehensive review on lipid oxidation in meat and meat products. Antioxidants 2019, 8, 429. [CrossRef] 
48. Sun, X.; Guo, X.; Ji, M.; Wu, J.; Zhu, W.; Wang, J.; Cheng, C.; Chen, L.; Zhang, Q. Preservative effects of fish gelatin coating enriched with CUR/ $\beta C D$ emulsion on grass carp (Ctenopharyngodon idellus) fillets during storage at $4{ }^{\circ} \mathrm{C}$. Food Chem. 2019, 272, 643-652. [CrossRef] [PubMed]

49. Jonaidi Jafari, N.; Kargozari, M.; Ranjbar, R.; Rostami, H.; Hamedi, H. The effect of chitosan coating incorporated with ethanolic extract of propolis on the quality of refrigerated chicken fillet. J. Food Process. Preserv. 2018, 42, e13336. [CrossRef]

50. Sogut, E.; Seydim, A.C. The effects of chitosan- and polycaprolactone-based bilayer films incorporated with grape seed extract and nanocellulose on the quality of chicken breast fillets. LWT Food Sci. Technol. 2019, 101, 799-805. [CrossRef]

51. Pabast, M.; Shariatifar, N.; Beikzadeh, S.; Jahed, G. Effects of chitosan coatings incorporating with free or nano-encapsulated Satureja plant essential oil on quality characteristics of lamb meat. Food Control 2018, 91, 185-192. [CrossRef]

52. Fang, Z.; Lin, D.; Warner, R.D.; Ha, M. Effect of gallic acid/chitosan coating on fresh pork quality in modified atmosphere packaging. Food Chem. 2018, 260, 90-96. [CrossRef] [PubMed]

53. Nouri Ala, M.A.; Shahbazi, Y. The effects of novel bioactive carboxymethyl cellulose coatings on food-borne pathogenic bacteria and shelf life extension of fresh and sauced chicken breast fillets. LWT 2019, 111, 602-611. [CrossRef]

54. Mojaddar Langroodi, A.; Tajik, H.; Mehdizadeh, T.; Moradi, M.; Moghaddas Kia, E.; Mahmoudian, A. Effects of sumac extract dipping and chitosan coating enriched with Zataria multiflora Boiss oil on the shelf-life of meat in modified atmosphere packaging. LWT 2018, 98, 372-380. [CrossRef]

55. Abdou, E.S.; Galhoum, G.F.; Mohamed, E.N. Curcumin loaded nanoemulsions/pectin coatings for refrigerated chicken fillets. Food Hydrocoll. 2018, 83, 445-453. [CrossRef]

56. Alirezalu, K.; Pateiro, M.; Yaghoubi, M.; Alirezalu, A.; Peighambardoust, S.H.; Lorenzo, J.M. Phytochemical constituents, advanced extraction technologies and techno-functional properties of selected Mediterranean plants for use in meat products. A comprehensive review. Trends Food Sci. Technol. 2020, 100, 292-306. [CrossRef]

57. Pateiro, M.; Vargas, F.C.; Chincha, A.A.I.A.; Sant'Ana, A.S.; Strozzi, I.; Rocchetti, G.; Barba, F.J.; Domínguez, R.; Lucini, L.; do Amaral Sobral, P.J.; et al. Guarana seed extracts as a useful strategy to extend the shelf life of pork patties: UHPLC-ESI/QTOF phenolic profile and impact on microbial inactivation, lipid and protein oxidation and antioxidant capacity. Food Res. Int. 2018, 114, 55-63. [CrossRef]

58. Suman, S.P.; Joseph, P. Myoglobin chemistry and meat color. Annu. Rev. Food Sci. Technol. 2013, 4, 79-99. [CrossRef]

59. Zarringhalami, S.; Sahari, M.A.; Hamidi-Esfehani, Z. Partial replacement of nitrite by annatto as a colour additive in sausage. Meat Sci. 2009, 81, 281-284. [CrossRef]

60. OJEU Commission regulation (EU) no 2073/2005 of 15 November 2005 on microbiological criteria for foodstuffs. Off. J. Eur. Union 2005, L338, 1-26.

61. Alirezalu, K.; Yaghoubi, M.; Nemati, Z.; Farmani, B.; Mousavi Khaneghah, A. Efficacy of stinging nettle extract in combination with $\varepsilon$-polylysine on the quality, safety, and shelf life of rainbow trout fillets. Food Sci. Nut. 2021. [CrossRef]

62. Bazargani-Gilani, B.; Aliakbarlu, J.; Tajik, H. Effect of pomegranate juice dipping and chitosan coating enriched with Zataria multiflora Boiss essential oil on the shelf-life of chicken meat during refrigerated storage. Innov. Food Sci. Emerg. Technol. 2015, 29, 280-287. [CrossRef]

63. Duan, J.; Jiang, Y.; Cherian, G.; Zhao, Y. Effect of combined chitosan-krill oil coating and modified atmosphere packaging on the storability of cold-stored lingcod (Ophiodon elongates) fillets. Food Chem. 2010, 122, 1035-1042. [CrossRef]

64. Lorenzo, J.M.; Munekata, P.E.S.; Dominguez, R.; Pateiro, M.; Saraiva, J.A.; Franco, D. Main Groups of Microorganisms of Relevance for Food Safety and Stability: General Aspects and Overall Description. In Innovative Technologies for Food Preservation Inactivation of Spoilage and Pathogenic Microorganisms; Barba, F.J., Sant'Ana, A.S., Orlie, V., Koubaa, M., Eds.; Academic Press: Cambridge, MA, USA, 2017; pp. 53-107. ISBN 9780128110324.

65. Kanatt, S.R.; Chander, R.; Sharma, A. Chitosan and mint mixture: A new preservative for meat and meat products. Food Chem. 2008, 107, 845-852. [CrossRef]

66. Petrou, S.; Tsiraki, M.; Giatrakou, V.; Savvaidis, I.N. Chitosan dipping or oregano oil treatments, singly or combined on modified atmosphere packaged chicken breast meat. Int. J. Food Microbiol. 2012, 156, 264-271. [CrossRef] [PubMed] 